\title{
BESZÁMOLÓ A HARMADIK KÖZÉP-EURÓPAI REGIONÁLIS TUDOMÁNYI KONFERENCIÁRÓL
}

\author{
(Technická Univerzita v Košiciah, Kassa, 2009. október 7-9.)
}

\section{TAGAI GERGELY}

2009. október 7. és 9. között harmadik alkalommal került megrendezésre a KözépEurópai Regionális Tudományi Konferencia (CERS - Central European Conference in Regional Science). A kétévente megszervezett eseménynek Szlovákia ad otthont, azonban a korábbi alkalmaktól eltérően idén a helyszínválasztás nem a festöi elhelyezkedésủ tátrai üdülőfalura, a Gerlachfalvi-csúcs lábánál fekvő Nový Smokovecre esett. A szervező egyetem (Technická Univerzita v Košiciah) - melynek gazdaságtudományi karán müködik Szlovákia egyik neves regionális tudományi mühelye úgymond 'hazahozta' a rendezvényt, amelynek helyszíne így Kassa városa lett.

Maga a konferencia nem az egyetemen került lebonyolításra: a szervezők az egyetemi városrész panelrengetegéből egy hotelba helyezték át a rendezvényt, amely csak pár lépésre volt a történelmi belvárostól, és több konferenciateremmel is rendelkezett az esemény befogadására. A belváros közelsége lehetőséget adott Kassa történelmi emlékeinek megismerésére. A fötér állandó forgataga jól mutatta, hogy mennyire élénk és pezsgő is a város élete, számos kikapcsolódási lehetőséget és kulturális programot nyújtva az idelátogatóknak. Számtalan egyéb rendezvény is zajlott a konferencia idején, például csak néhány nappal azelött rendezték meg a 86. Kassai Béke Maratont, amely Európa legrégebbi ilyen típusú futóversenye.

A konferencia nem egy központi téma köré szervezödött, inkább kongresszus jellegünek nevezhetnénk (ha méretét, résztvevöi létszámát tekintve nem is), ahol a környező országok regionalistái, szakmabelijei cserélhették ki egymással tapasztalataikat, és oszthatták meg újabb kutatási eredményeiket a regionális tudomány területéről, szigorúan szabott tematikai kötöttségektől mentesen. Így elötérbe kerültek az aktuális gazdasági és társadalmi kérdéseket regionalista szemszögbőll taglaló előadások, amelyek az elméleti indíttatású vagy módszertani jellegủ, és ezeket esettanulmányokkal megtámogató munkákkal együtt alkották a prezentációk derékhadát.

A rendezvény nyitányaként plenáris ülésre került sor, amelyen az európai kutatói közösség négy neves tagja vezette elő aktuális kutatásait. Roberta Capello, a Nemzetközi Regionális Tudományi Táraság (RSAI) elnöke a regionális gazdaságtan tudományának elmúlt ötven évét értékelte, kiemelve, hogy egy relatíve fiatal diszciplínaként a regionális gazdaságtannak még számtalan elméleti és módszertani 'rést' kell feltöltenie. A tudományág eddig elért eredményei ennek megfelelően számos olyan kérdést vetnek fel, amelyek a jövőbeni irányok szempontjából kihívásként, kritikai közelítést igényelve merülnek fel. Peter Nijkamp (VU 
University, Amszterdam), a konferencia egyik visszatérő előadója az ún. 'smart cities' (okos városok) koncepciójáról beszélt. Elóadásában kiemelte, hogy a városok gazdasági teljesítóképessége napjainkban nem elsősorban az infrastrukturális és egyéb 'kemény' tényezőktől függ, hanem mindinkább a humán tőke, az elérhetőség, a városi környezet állapota, valamint nem utolsósorban a kommunikáció és tudásközvetítés minősége (pl. ICT - Információs és Kommunikációs Technológiák elterjedtsége) határozzák meg. Ennélfogva a városfejlődést alakító irányelvek megfogalmazásánál fóként az utóbbi tényezőkre kell tekintettel lenni. Manfred $M$. Fischer, a Bécsi Gazdasági és Üzleti Egyetem (Vienna University of Economics and Business) professzora prezentációjában egy térökonometriai növekedési modellt mutatott be, melynek hangsúlya a gazdasági növekedés fizikai és humán tényezői mellett a régiók kölcsönös technológiai függésére helyeződött, mint ami nagymértékben befolyásolja a tudásáramlás - és ezzel a gazdasági fejlődés - lehetőségeit. Szintén visszatérő előadó volt Adrian Smith is (Queen Mary University, London), aki a szlovákiai ruhaipar elmúlt évtizedeinek eseményein keresztül mutatta be a gazdasági és társadalmi környezet átalakulását az országban, egyúttal az európai integráció, a globalizáció és a gazdasági válság folyamatait is értékelve.

A konferencia további előadásai a tematikai szabadság mellett négy témacsoportba keriiltek besorolásra, úgymint: regionális tudomány és alkalmazásai az európai országokban, regionális versenyképesség és innováció, határon átnyúló együttmüködés és fejlödés, valamint decentralizáció és regionális politika. E témacsoportokra maguk a jelentkezök tehettek ajánlást. A mintegy 110 előadás több mint fele, besorolása alapján, valamiképpen a regionális versenyképesség témájához kapcsolódott, jelezve ezzel a kérdéskör aktualitását a regionális tudományi kutatásokban. A versenyképesség hívószava ebben az esetben maga is számos nagyobb tématerületet ölelt át. Több előadó foglalkozott a regionális versenyképesség elméleti és általános kérdéseivel: mérésének lehetőségeivel, humán és fizikai tényezőinek felmérésével, valamint teruileti és intézményi összefüggéseivel. Számos prezentációban külön hangsúly helyeződött az innováció, mint versenyképességi tényező szerepének értékelésére. Ennek kapcsán, a különbözö ágazati innovációs lehetőségek bemutatása mellett, elsősorban az innováció (regionális innováció) stratégiai és kohéziós funkciójának megvitatására helyeződött a hangsúly, illetve több előadás kiemelte az egyetemek, mint tudásközvetítő intézmények szerepét az innovációs folyamatokban. Szintén a versenyképesség tág tématerületéhez kapcsolódóan - de egymással is összefüggésben - került sor több olyan előadásra, amelyek a teruileti fejlódés, fenntartható fejlődés, életminőség kérdésével foglalkoztak.

Ennek kapcsán már jelentős átfedés volt tapasztalható a kifejezetten elméleti és módszertani jellegủ prezentációkkal, amelyek szintén nagyobb számmal szerepeltek a konferencia programjában. Ezt a tábort gazdagították a különböző fejlődéselméletek értékelését és adaptálását, a gazdasági fejlettség és területi különbségek tényezöit és térségi összefüggéseit bemutató elöadások, és az ezen jelenségek mérési lehető́ségeit kutató munkák. A 'felkapottabb' témákkal szemben a határon átnyúló együttműködésre vonatkozó és gyakorlati (fejlesztéspolitikai) kérdéseket taglaló elóadások a 
konferencia programjának relatíve kis hányadát alkották. Igaz azonban, hogy a szélesebb résztvevői körủ témák elöadói rendszerint megfogalmaztak bizonyos ajánlásokat a regionális politika döntéshozói számára kutatásaik alapján.

A konferencia prezentációi által felölelt tématerületek sok szempontból a regionális tudomány régi-új, de mindig aktuális kutatási irányait alkotják. Újszerüséget ebből a szempontból elsősorban egyes módszertani megoldások bemutatása jelentett, illetve az elméletek bizonyos terïletekre alkalmazott adaptációja hozott. Tematikai nóvumot a gazdasági válság napjainkban megkerülhetetlen, térfolyamatokat átalakító szerepének kiemelése - és sajnálatos aktualitása - rejtett magában. A jelenség és tényezőinek vizsgálatát helyezte középpontba több elöadás, amelyek a fenti témákhoz kapcsolódóan értékelték az aktuális gazdasági és társadalmi folyamatokat.

A legtöbb résztvevó természetesen Szlovákiából (elsősorban a helyi egyetemről) érkezett, de a második legnépesebb részt vevő nemzet, a magyar nem sokkal maradt el ettôl létszámában. Nagyobb számban jöttek előadók még más környező országokból, Csehországból, Lengyelországból és Ukrajnából is: a konferencia valóban leginkább a szúken vett (kelet-)közép-európai térség regionalistáinak érdeklődését váltotta ki. De emellett regisztráltak résztvevőt/előadót például Portugáliából, Finnországból, Törökországból, az Egyesült Államokból, de még a Dél-afrikai Köztársaságból is. Magyarországról elsősorban az egyetemi regionális tudományi mủhelyek kutatóit aktivizálta a rendezvény: több előadó érkezett a konferenciára Miskolcról, Pécsről, Szegedröl, illetve Budapeströl, a Corvinus Egyetemről, a Müszaki és Gazdaságtudományi Egyetemről, valamint az Eötvös Loránd Tudományegyetemröl. A hazai kutatók előadásai tematikusan beleilleszkedtek az aktuális nemzetközi tudományos irányzatokba, de ez elmondható más országok kutatói közösségéről is. Látható, hogy hasonló kérdések érintik meg a környező országok regionalistáit: a konferencián hasonló témák találkoztak egy-egy, más országból származó kutató prezentációjánál, így a különböző területre készített esettanulmányok, helyi vizsgálatok jól szolgálták az összehasonlítást és az eltérő felfogások ütköztetését.

A tematikai besorolások mellett a konferencia előadásai javarészt, a nyitónap zsúfoltabb programját leszámítva, két párhuzamos szekcióban zajlottak. Ezek közül az egyik külön a fiatal - 33. életévüket be nem töltött - kutatók számára volt fenntartva. Ez a szekció különösen sikeresnek mondható, hiszen 60 (!) fiatal előadó (vagy páros) vállalta, hogy megméretteti munkáját. A dolog nem volt 'tét' nélküli: az előadások alapját képező tanulmányokat már korábban bekérték a szervezők, amelyeket azután a konferencia tudományos tanácsának tagjai véleményeztek. Bírálatukat sajnos nem kaptuk kézhez, így csak a prezentációk alkalmával volt lehetőség mások szakmai véleményének megismerésére. Azonban túlságosan tág teret erre a szekciók menetrendje sem adott, hiszen a szigorú moderálás mellett egy-egy résztvevőre csak 15 perc jutott - szemben a plenáris és egyéb elöadások 30-40, valamint 20-25 percével. A kérdésekre és hozzászólásokra szánt kis idő általában azért megfelelö visszajelzésekkel járt. Sőt, alkalmanként érdemi vitához is vezetett, amely a konferencia talán legjobb pillanatait hozta. Egy alkalommal, két professzor parázs disputája során - egy előadó megállapításainak védelmében, illetve ellenében -, körbepillantva 
ugyanazt a sugárzó érdeklődést lehetet látni minden arcon - a közönség élvezettel figyelte a ritkán hallható szakmai szópárbajt. A legjobbnak ítélt előadásokat/pályamunkákat oklevéllel és anyagi elismeréssel is honorálták. Ezen a téren magyar sikerről is beszámolhatunk, hiszen egy helyi illetőségü, illetve egy horvátországi fiatal kutató, valamint egy cseh szerzőpáros mellett díjazott 'helyezést' ért el Jeney László, a Budapesti Corvinus Egyetem Gazdaságföldrajz Tanszékének adjunktusa, 'A Visegrádi országok város-vidék fejlettségi különbségeinek ágazati háttere' címủ előadásával.

A rendezvényhez több közösségi szabadidös program is tartozott. Az első nap a szlovák kultúrát és gasztronómiát bemutató estet rendeztek a szervezők, majd a konferencia további ideje alatt sor került egy bowling-bajnokságra, egy tokaji bortúrára és egy közös városnézésre, idegenvezetéssel. A konferencia záróeseménye pedig egy kirándulás volt, melynek résztvevői Kraszna Horka várába látogattak el, illetve a Szlovák-karszt barlangjaival ismerkedhettek meg. A rendezvény záróülésén az elnökség ígéretet tett a negyedik, két év múlva megrendezendő KözépEurópai Regionális Tudományi Konferencia megszervezésére; ennek helyszínéröl még nem született döntés. Az elhangzott előadások konferenciakötetben kerülnek publikálásra, amely egy ISBN számmal ellátott elektronikus könyv formájában jelenik majd meg, és feltehetöleg - a korábbi gyakorlatnak megfelelöen - a rendezvény honlapján (www.cers.tuke.sk) is hozzáférhető lesz. 